\title{
INVESTIGAÇÕES GEOFÍSICAS NA BORDA DA BACIA SEDIMENTAR DE SÃO PAULO, UTILIZANDO-SE GPR E ELETRORRESISTIVIDADE
}

\author{
Welitom Rodrigues Borges \\ Orientador: Dr. Jorge Luís Porsani (IAG/USP) \\ 153p - Dissertação (Mestrado) - Defesa 20.03.2002
}

\begin{abstract}
RESUMO. Nesta pesquisa foram empregados os métodos geofísicos Ground Penetrating Radar-GPR e Eletrorresistividade visando caracterizar geologicamente os sedimentos e o topo do embasamento granítico-gnáissico da Bacia Sedimentar de São Paulo. Além disso, foram realizados furos de sondagens a trado até $5 \mathrm{~m}$ de profundidade, visando detalhar a subsuperfície rasa. Esta pesquisa faz parte do Projeto Temático FAPESP, dentro do qual foram executadas perfurações de 3 poços de investigação geológica com $80 \mathrm{~m}$ de profundidade. A área de estudos está localizada dentro do Campus da Universidade de São Paulo. A Bacia de São Paulo possui uma área de aproximadamente $1800 \mathrm{~km}^{2}$ e espessura máxima de $310 \mathrm{~m}$, sendo caracterizada litologicamente por sedimentos areno-argilosos do Grupo Taubaté e da Formação Itaquaquecetuba, assentados, em sua maioria, sobre um embasamento granito-gnaíssico. Os dados GPR e de eletrorresistividade foram adquiridos em duas áreas, sendo uma localizada em frente ao prédio do Instituto de Astronomia, Geofísica e Ciências Atmosféricas (IAG/USP) e outra numa área próxima ao Instituto de Pesquisas Energéticas e Nucleares (IPEN). Os perfis geofísicos foram realizados ao longo de uma mesma linha, visando a comparação dos resultados obtidos com diferentes metodologias. Os perfis GPR adquiridos em frente ao IAG/USP, com $200 \mathrm{~m}$ de comprimento, foram adquiridos com antenas de 25, 50, 100 e $200 \mathrm{MHz}$. Os perfis de Caminhamentos Elétricos (CE) foram adquiridos com espaçamento entre os dipolos de 10 e de 20 metros. Além disso, as medidas das Sondagens Elétricas Verticais (SEV's) foram posicionadas sobre estes perfis, utilizando-se os arranjos Schlumberger e Dipolar. Após o processamento e interpretação dos dados geofísicos, com base nas informações geológicas obtidas através dos poços de investigação geológica e perfis a trado, foi possível avaliar a potencialidade de utilização do método GPR e da Eletrorresistividade na borda da Bacia Sedimentar de São Paulo. 0 método GPR mostrou-se eficaz no imageamento de estruturas da subsuperfície até $14 \mathrm{~m}$ de profundidade, identificando a base do aterro e o topo da camada de areia grossa. Não foi possível atingir maiores profundidades devido a atenuação da onda eletromagnética provocada pelo espesso pacote sedimentar condutivo. As SEV's (arranjo Schlumberger) identificaram horizontes geoelétricos resistivos e condutivos, correlacionados com os sedimentos da Bacia de São Paulo até cerca de $43 \mathrm{~m}$ de profundidade. As SEV's (arranjo Dipolar) permitiram identificar o embasamento na área em frente ao IAG/USP a uma profundidade de 43 a $47 \mathrm{~m}$, mergulhando para NW em direção a Prefeitura do Campus Universitário. Os perfis de CE permitiram imagear claramente variações faciológicas nos sedimentos da Formação São Paulo. Os resultados geofísicos apresentam um excelente ajuste com as informações geológicas provenientes dos poços de investigação geológica, furos a trado e um perfil de reflexão sísmica, o que coloca os métodos GPR e de eletrorresistividade, integrados, como sendo promissores para a caracterização geológica da subsuperfície rasa na borda da Bacia Sedimentar de São Paulo.
\end{abstract}

ABSTRACT. In this work, the Ground Penetrating Radar - GPR and Resistivity methods were used aiming at characterize geologically the sediments and the top of the granitic basement of the Sedimentary Basin of São Paulo. Moreover, manual probing a depth of to $5 \mathrm{~m}$ in order to detail the shallow subsurface and 3 boreholes of approximately $80 \mathrm{~m}$ of depth were dug as part of this research. The study area is located inside the São Paulo's University Campus. The Sedimentary Basin of São Paulo has an area of approximately $1800 \mathrm{~km}^{2}$ and maximum thickness of $310 \mathrm{~m}$. It is characterized lithologically by clays and sands of the Taubaté Group and of the Itaquaquecetuba Formation, reposing, usually, over a granitic basement. The GPR and resistivity data were acquired in two areas, one located in front of the Astronomy, Geophysics and Atmospheric Sciences Institute (IAG/USP) and another near area to the Nuclear, Energy Researches Institute (IPEN). The geophysical profiles were performed along a same line, aiming at comparison of the results obtained with different methodologies. The GPR profiles acquired in front of the IAG/USP, with $200 \mathrm{~m}$ of length, were surveyed with antennas of 25, 50, 100 and $200 \mathrm{MHz}$. Electric Profiles (EP) were acquired with dipole spacing of 10 and of 20 meters. Moreover, the points of the Vertical Electric Soundings (VES's) were positioned on these profiles. The Schlumberger and Dipole-Dipole array were employed for the VES survey. Based on the processing and interpretation of the geophysical data, and the geological information obtained through boreholes and manual probing holes. It was possible to evaluate the utilization potentiality of the GPR and resistity method at the border of the Sedimentary Basin of São Paulo. The GPR method proved effective to map structures of subsoil down to $14 \mathrm{~m}$ of depth, identifying the bottom boundary of the soil and one coarse sand layer. The thick conductive sediments didn't allow the GPR to reach larger depths. VES's (Schlumberger array) identified resistive and conductive horizons, correlated with the São Paulo Basin sediments within about $43 \mathrm{~m}$ of depth. VES's (Dipole-Dipole array) allowed to identify the basement in the area in front of IAG/USP to a depth range from 43 to $47 \mathrm{~m}$, dipping NW to the of Campus Municipality. Electric Profiles (EP) allowed to identify lateral variations in sediments of the São Paulo Formation. The geophysical results present an excellent correlation with the geological information of the boreholes, manual probing holes and a seismic reflection profile. It was concluded that the GPR and resistivity methods are promising for the geological characterization of shallow subsurface mapping at the border of the Sedimentary Basin of São Paulo. 